\title{
Zofia RZEŹNICKA*
}

Maciej KOKOSZKO**

\section{PROSO W GASTRONOMII ANTYKU I WCZESNEGO BIZANCJUM ${ }^{1}$}

W starożytności i epoce bizantyńskiej znano dwa podstawowe gatunki pro-

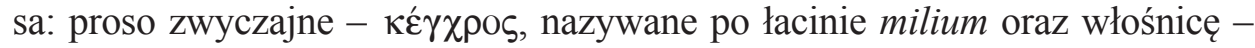
$\varepsilon ’ \lambda v \mu o \varsigma, \mu \varepsilon \lambda \lambda^{\prime} v \eta$, po łacinie, panicum ${ }^{2}$. Nie były one wykorzystywane w grecko-rzymskiej ${ }^{3}$ gastronomii tak powszechnie ${ }^{4}$ jak jęczmień czy pszenica. Ich spożycie wzmiankowane jest jednak w źródłach częściej niż w przypadku owsa bądź ryżu. Nie oznacza to, że dysponujemy wystarczającą ilością materiałów, by pisząc o ich zastosowaniu kulinarnym, nie odwoływać się do analogii z innymi zbożami. Ze względu na znikomą liczbę wzmianek na temat prosa w stricte kulinarnym piśmiennictwie będziemy sięgać zarówno do literatury pięknej, agronomicznej, leksykograficznej, jak i medycznej interesującej nas epoki. Dzieła z tej ostatniej dziedziny są dla nas szczególnie ważne, gdyż znakomicie odzwierciedlają główne trendy panujące w gastronomii na przestrzeni wieków.

Sytuacja taka dotyczy chociażby informacji na temat pieczywa z mąki jaglanej. Z zapisków pozostawianych przez Dioskuridesa (I w. po Chr.) wypa-

${ }^{*}$ Mgr Zofia Rzeźnicka - doktorantka przy Katedrze Historii Bizancjum w Instytucie Historii na Wydziale Filozoficzno-Historycznym Uniwersytetu Łódzkiego; e-mail: zosia_pwp.historyk@wp.pl.

** Dr hab. Maciej Kokoszko, prof. UŁ - kierownik Katedry Historii Bizancjum w Instytucie Historii na Wydziale Filozoficzno-Historycznym Uniwersytetu Łódzkiego; e-mail: mkokoszko@ komandor.pl.

${ }^{1}$ Artykuł został napisany w związku z grantem 2011/01/BHS3/01020.

${ }^{2}$ Por. A. Dalby, Food in the Ancient World from A to Z, London, New York 2003, 219.

${ }^{3}$ Z przekazu Pliniusza Starszego (Historia naturalis XVIII 24, 100; w niniejszym opracowaniu posługiwano się wydaniem: Pliny, Natural History, with an English Translation in Ten Volumes, transl. H. Rackham, London - Cambridge Mass. 1938-1963) dowiadujemy się, że proso i jęczmień były jedynymi gatunkami zbóż znanymi w Etiopii. Prawdopodobnie więc stanowiły tam podstawę pożywienia. Strabon (Geographica V 1, 12; IV 1, 2; 2, 1; w niniejszym opracowaniu posługiwano się wydaniem F. Lasserre: Strabon, Géographie, t. 2: Livres III-IV, Paris 1966; t. 3: Livres V-VI, Paris 1967) pisze o uprawie prosa w Galii Cisalpejskiej, Narbońskiej i nieurodzajnych plonach w Akwitanii. O rozległych uprawach zarówno prosa jak i włośnicy w Galii Cisalpejskiej, zob. Polybius, Historiae II 120, 15; w niniejszym opracowaniu posługiwano się wydaniem Polybii Historiae, editionem a L. Dindorfio curatam retractavit T. Büttner-Wobst, I-V, Lipsiae 1889-1905.

${ }^{4}$ O spożywaniu prosa i włośnicy, zob. Dioscurides Pedanius, De materia medica lib. II 98, 1, 1-4; w niniejszym opracowaniu posługiwano się wydaniem: Pedanii Dioscuridis Anazarbei De materia medica libri quinque, ed. M. Wellmann, I-III, Berolini 1906-1914. 
da wnioskować, iż nie było znacznej różnicy między wykorzystaniem prosa i włośnicy ${ }^{6} \mathrm{w}$ celach kulinarnych. Oba zboża mielono, by z uzyskanej mąki ${ }^{7}$ wypiekać chleb ${ }^{8}$, który zapewne był dość popularny, choć wiemy także, iż nie wszyscy go cenili ${ }^{9}$. Kolumella w swoim traktacie agronomicznym twierdził jednak, że gorące pieczywo z mąki uzyskanej z prosa jeść można z przyjemnością ${ }^{10}$. Tego rodzaju pokarm o „bardzo słodkim” (praedulcis) smaku był popularny zwłaszcza w Kampanii ${ }^{11}$. Również w epoce Galena (II-III w.) proso uważano za roślinę, której ziarno nadawało się do przygotowania chleba ${ }^{12}$, ale

\footnotetext{
${ }^{5}$ Por. Dioscurides Pedanius, De materia medica II 97, 1, 2-3.

${ }^{6}$ Zdaniem Pliniusza (Historia naturalis XVIII 10, 54) chleb z włośnicy wypiekany był dość rzadko; por. J. André, L'alimentation et la cuisine à Rome, Paris 1961, 66. Nie znaczy to, że gatunek ten w ogóle nie znalazł zastosowania w kuchni. Atenajos w Deipnosofistach (III 109b-c; w niniejszym opracowaniu posługiwano się wydaniem Athenaei Naucratitae Dipnosophistarum libri $X V$, recensuit G. Kaibel, I-III, Lipsiae 1887-1890) przytacza fragment dzieła Tryfona z Aleksandrii

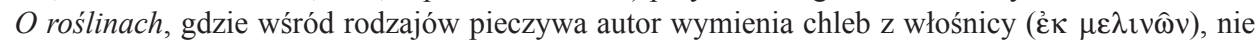
wspominając przy tym o jego gorszej jakości. Włośnica konsumowana była w Galii, zwłaszcza w Akwitanii. Cieszyła się popularnością również w Italii, szczególnie wśród mieszkańców okolic Padu. Jednak najchętniej spożywana była przez ludy zamieszkujące obszary położone nad Morzem Czarnym (zob. Plinius, Historia naturalis XVIII 25, 101). Konsumpcja kaszy pozyskanej z wło-

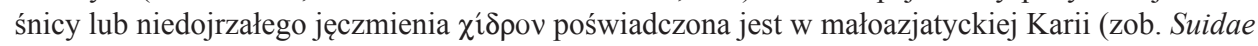

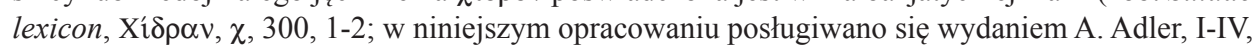
Lipsiae 1928-1935.

${ }^{7}$ Por. Dioscurides Pedanius, De materia medica V 3, 3, 4. Jeden z jej rodzajów nazywany jest przez Diskuridesa ő̉ $\lambda \varepsilon v \rho o v$. Świadectwo pozyskiwania mąki z prosa i włośnicy, zob. Plinius, Historia naturalis XVIII 23, 99.

${ }^{8}$ Por. Dioscurides Pedanius, De materia medica II 97, 1, 1-2.

${ }^{9}$ Por. refleksje Galena na ten temat. Nie oznacza to, że chleb ten był całkowicie pozbawiony jakichkolwiek zalet. Żyjący na przełomie I w. przed Chr. i I w. po Chr. rzymski encyklopedysta Aulus Cornelius Celsus pisze na przykład, że pieczywo z prosa jest pożywniejsze/silniejsze w działaniu od przygotowanego z mąki jęczmiennej, choć w tym samym stopniu wpływa niekorzystnie na pracę żołądka, zob. Aulus Cornelius Celsus, De medicina II 18, 4; II 30, 1; II 25, 1 (w niniejszym opracowaniu posługiwano się wydaniem: Celsus, De medicina, with an English Translation by W.G. Spencer in Three Volumes, I-III, London - Cambridge Mass. 1960-1961); André, L'alimentation, s. 66. Ciekawą informację na temat właściwości chleba z mąki jaglanej odnajdujemy też w Geoponikach (XIV 24, 4; w niniejszym opracowaniu posługiwano się wydaniem: Geoponica sive Cassiani Bassi Scholastici de re rustica eclogae, recensuit H. Beckh, Lipsiae 1895). Wypieczone z niej pieczywo traktowane było jako niezawodna ochrona przed truciznami. Rozdział dwudziesty czwarty księgi czternastej pochodzi od Didymosa.

${ }^{10}$ Por. Lucius Junius Moderatus Columella, Res rustica II 9, 19; w niniejszym opracowaniu posługiwano się wydaniem: On Agriculture, with a recensione on the Text and an English Translation by H. Boyd Ash (I), E.S. Forster - E.H. Heffner (II-III), I-III, London - Cambridge Mass. 1960-1979.

${ }^{11}$ Por. Plinius, Historia naturalis XVIII 24, 100; André, L'alimentation, s. 66.

${ }^{12}$ Por. Galenus, De alimentorum facultatibus lib. 523, 9 - 524, 10; w niniejszym opracowaniu posługiwano się wydaniem: G. Helmreich, w: Galeni De sanitate tuenda libri VI, De alimentorum facultatibus libri III, De bonis malisque sucis liber, De victu attenuante liber, De ptisana liber, Lipsiae - Berolini 1923, 199-386. Ziarno prosa uważane było za niezwykle ciężkie, a jego objętość wzrastała w trakcie obróbki termicznej. W ten sposób z jednego modiusa
} 
właściwie tylko w czasach nieurodzaju innych zbóż $\dot{z}^{13}$. Wypieki z mąki jaglanej były jednak opisywane jako bardzo kruche, ponieważ - zdaniem lekarza - nie zawierają w sobie substancji spajających ${ }^{14}$. Żywność tego typu była raczej pokarmem wieśniaków ${ }^{15}$. Zapewne zatem do jej produkcji nie wykorzystywano skomplikowanych urządzeń, a ceny na nią (jak i na surowiec, z którego ją wytwarzano) - jeżeli w ogóle pokarm ten trafiał na rynek (zwłaszcza miejski) - były niewygórowane. Stąd też jeszcze w kolejnych stuleciach taktowany był przede wszystkim jako pożywienie ubogiej ludności ${ }^{16}$.

Do dzisiejszych czasów nie zachował się żaden z ówczesnych przepisów na pieczywo, wymagający użycia mąki pozyskanej z omawianego zboża. Nie jest to jednak przeszkodą dla naszych rozważań, ponieważ - jak zauważa Pliniusz Starszy - z mąki otrzymanej z prosa zwyczajnego przygotowywano wiele rodzajów chleba (panis multifariam) ${ }^{17}$. Poświęcimy zatem nieco uwagi praktykom związanym z przyrządzaniem chleba od momentu wyrobienia ciasta do jego upieczenia. Sądzimy bowiem, że był to proces, na którego przebieg nie miało wpływu wykorzystanie mąki z konkretnego gatunku zboża. Niewykluczone zatem, że wykorzystywano ją również w gospodarstwie Katona podczas przyrządzania panis depsticius ${ }^{18}$. Aby przygotować ten rodzaj pieczywa należało wsypać mąkę do dokładnie umytego moździerza, stopniowo dolewać do niej wodę, a powstałe w ten sposób ciasto ugnieść. Następnie wałkowano je i pieczono pod glinianą przykrywką ${ }^{19}(\text { sub testu })^{20} . \mathrm{Z}$ treści przepisu Marka Porcjusza wynika, że ciasto powinno zostać wyrobione w moździerzu.

$(8,75$ l) prosa otrzymywano sześćdziesiąt funtów (funt $=27,3 \mathrm{~g})$ chleba, zob. Plinius, Historia naturalis XVIII 10, 54.

${ }^{13}$ Informacje Galena zostały potem powtórzone przez Orybazjusza, por. całościową charakterystykę prosa i włośnicy, Oribasius, Collectiones medicae, I 15, 1, 1 - 4, 4; w niniejszym artykule posługiwano się wydaniem: Oribasii Collectionum medicarum reliquiae, ed. I. Raeder, I-IV, Lipsiae - Berolini 1928-1933. O pieczeniu chleba z mąki jaglanej w czasach nieurodzaju zob. L.D. Thurmond, A Handbook of Food Processing in Classical Rome, Leiden - Boston 2006, 17; J.M. Wilkins - S. Hill, Food in the Ancient World, Malden - Oxford - Victoria 2006, 118-119.

${ }^{14}$ Por. Galenus, De alimentorum facultatibus lib. 523, 10-11 (glischron).

${ }^{15}$ Por. tenże, In Hippocratis de victu acutorum commentaria 88, 35-36; w niniejszym opracowaniu posługiwano się wydaniem: Galeni In Hippocratis de victu acutorum commentaria, ed. G. Helmreich, Lipsiae 1914.

${ }^{16}$ Por. Hieronymus, Epistula 52, 6, ŹMT 55 [wyd. łacińsko-polskie, tekst łac. oprac. H. Pietras, tłum. J. Czuj, oprac. M. Ożóg], Kraków 2010, 17; Wilkins - Hill, Food in the Ancient World, s. 118119; André, L'alimentation, s. 66.

${ }^{17}$ Plinius, Historia naturalis XVIII 10, 54. Na temat różnorodności pieczywa w antyku pisze Atenajos. W jego Deipnosofistach (III 109 b - 115 f) zachowały się wypisy z dzieł poświęconych wyłącznie pieczywu, jak Wypiek chleba Chrysipposa z Tyany lub fragmenty traktatów bądź utworów scenicznych wzmiankujących tę kwestię.

${ }^{18}$ Zwrot ten dosłownie oznacza: „,chleb ugnieciony”.

${ }^{19}$ Por. Cato Marcius Porcius, De agri cultura LXXIV; w niniejszym opracowaniu posługiwano się wydaniem: M. Porci Catonis De agri cultura liber, rec. H. Keil, Lipsiae 1895.

${ }^{20}$ Ten sposób pieczenia omówiony zostanie w dalszej części artykułu. 
Wiemy, że mogły do tego służyć również specjalne kamienne, drewniane lub wykonane $\mathrm{z}$ terakoty ${ }^{21}$ stoły o podwyższonych kantach $^{22}$. Natomiast przy jego większej ilości wykorzystywano specjalne urządzenia poruszane przez ludzi lub zwierzęta pociągowe ${ }^{23}$.

Część pieczywa powstawała na zakwasie pozyskiwanym ze sfermentowanego ciasta z poprzedniego wypieku, bądź ze skwaszonych żytnich plac$\mathrm{ków}^{24}$. Dla naszych badań istotne jest, że proso wykorzystywano w Rzymie do produkcji jednego z zaczynów. W tym celu ugniatano ciasto z mąki jaglanej i moszczu winnego, które po ususzeniu nie traciło swoich właściwości przez cały $\operatorname{rok}^{25}$. Prawdopodobnie, po tak długim czasie, zakwas przed dodaniem do ciasta rozmiękczano wodą i pozostawiano w cieple, by drożdże mogły się namnożyć. Inną metodę stosowano w Galii i Hiszpanii, gdzie proso lub otręby łączone były z drożdżami piwnymi ${ }^{26}$. Chleby modelowano ręcznie lub za pomocą form ${ }^{27}$. Należy pamiętać, że ówczesne pieczywo nie przypominało znanych nam bochenków, lecz raczej placki, czy podpłomyki. Znane są przede wszystkim okrągłe chleby, których dzielenie miały ułatwić odśrodkowe nacięcia ${ }^{28}$. Od nich pieczywo wzięło swoją nazwę: o้ $\rho \tau o \varsigma ~ \beta \lambda \omega \mu \iota \alpha \hat{\imath} \tau o \varsigma^{29}$,

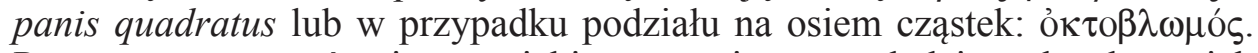
Przygotowywano również wypieki o rozmaitym wyglądzie, a każdy z nich charakteryzował się nie tylko oryginalnym kształtem, ale też smakiem, który zapewniały odpowiednie dodatki. Wypiekano chociażby pieczywo wyglądem przypominające kostki do gry - кúßor - przyprawiane koprem, serem i oliwą ${ }^{30}$, bułki z mąki pszennej - кó $\lambda \lambda \alpha \beta \mathrm{ot}^{31}$, które prawdopodobnie miały kształt

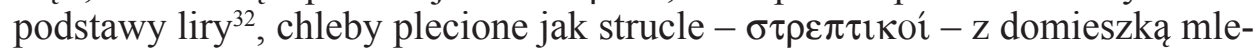

${ }^{21}$ Por. B.A. Sparkes, The Greek Kitchen, „Journal of Hellenic Studies” 82 (1962) 126.

${ }^{22}$ Por. L. Winniczuk, Chleb u starożytnych Greków i Rzymian, „Meander” 5 (1950) 235.

${ }^{23}$ Por. tamże, s. 234. O wykorzystaniu zwierząt do pracy w młynie zob. Lucius Apuleius, Metamorphoses IX 11-13; w niniejszym opracowaniu posługiwano się wydaniem: The Golden Ass. Being the Metamorphoses of Lucius Apuleius, with an English Translation by W. Adlington revised by S. Gaselee, London - Cambridge Mass. 1958; M. Griffith, Horsepower and Donkeywork: Equids and the Ancient Greek Imagination, CPh 3 (2006) 225; J.P. Alcock, Food in the Ancient World, Westport - London 2006, 113-114.

${ }^{24}$ Por. Winniczuk, Chleb u starożytnych, s. 234-235.

${ }^{25}$ Por. Plinius, Historia naturalis XVIII 26, 102. Zob. Thurmond, A Handbook of Food Processing, s. 62; R.J. Forbes, Studies in Ancient Technology, III, Leiden 1965, 97.

${ }^{26}$ Por. Winniczuk, Chleb u starożytnych, s. 235.

${ }^{27}$ Por. tamże.

${ }^{28}$ Por. tamże, s. 242.

${ }^{29}$ Athenaeus, Deipnosophistae III 114e. Greckie słowo $\beta \lambda \omega \mu$ ó oznacza: „kawałek”, „,kęs chleba", por. Abramowiczówna I 430.

${ }^{30}$ Por. Athenaeus, Deipnosophistae III 114a. Zob. Winniczuk, Chleb u starożytnych, s. 242.

${ }^{31}$ Athenaeus, Deipnosophistae III, $110 \mathrm{f}$.

${ }^{32}$ Por. Winniczuk, Chleb u starożytnych, s. 242. Greckie słowo кó $\lambda \lambda \alpha \beta$ $\alpha$ oprócz bułki oznacza też kołek liry służący do naciągania strun, por. Abramowiczówna II 687. 
ka, niedużym dodatkiem pieprzu, oliwy lub thuszczu zwierzęcego $0^{33}$ lub kształcie grzyba - $\beta \omega \lambda \eta \dot{\tau} \tau$ vor - z makiem ${ }^{34}$.

Nazwy chlebów mogły pochodzić od produktów, z którymi komponowały się smakowo, np. ostryg - ostrearius ${ }^{35}$, lub od stopnia delikatności wypieków - $\alpha \pi \alpha \lambda$ ó $^{36}$, artolaganus ${ }^{37}$. Wiele otrzymało miano od metody pieczenia: bezpośrednio na rozgrzanych węglach - $\alpha \pi 0 \pi v \operatorname{pí}^{\alpha} \varsigma^{38}$, nad paleniskiem

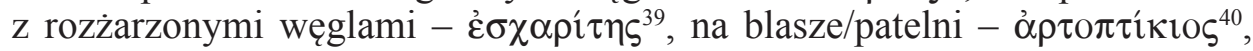

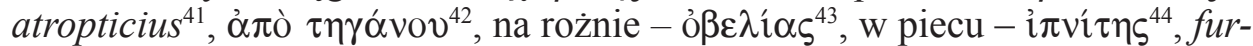

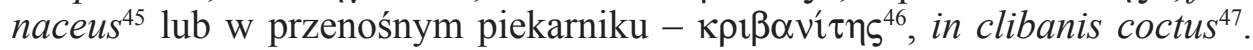
Powyższe przykłady dowodzą, że znano wiele sposobów wypieku pieczywa, a brak pieca, czy piekarnika rekompensowały inne przyrządy kuchenne. Najprostszą metodą było umieszczenie na rozgrzanym palenisku dachówki, którą po położeniu na niej ciasta otaczano gorącym popiołem ${ }^{48}$. Inna technika polegała na ustawieniu nad paleniskiem rusztu, na którym kładziono patelnię lub garnek z mającym upiec się bochenkiem ${ }^{49}$. Wykorzystywano też bardziej fachowe przyrządy jak duży piec piekarski - furnus, jego mniejszą wersję furniculus, grecki i $\pi v o ́ s$, czy wspomniany wyżej przenośny piekarnik - testum.

Pierwszy z wymienionych, ze względu na swój rozmiar, mieścił większe ilości chleba ${ }^{50}$. Mógł zostać zbudowany z różnego rodzaju materiałów: kamie-

${ }^{33}$ Athenaeus, Deipnosophistae III 113d. Por. Winniczuk, Chleb u starożytnych, s. 242.

${ }^{34}$ Athenaeus, Deipnosophistae III, 113c.

${ }^{35}$ Plinius, Historia naturalis XVIII 27, 105.

${ }^{36}$ Athenaeus, Deipnosophistae III 113b. Słowo ó $\pi \alpha \lambda$ ó znaczy: „delikatny, miękki”, por. Abramowiczówna I 239.

${ }^{37}$ Plinius, Historia naturalis XVIII 27, 105. Forma ta powstała zapewne od greckiego słowa

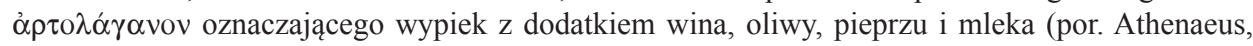
Deipnosophistae III 113d).

${ }^{38}$ Athenaeus, Deipnosophistae III, 111e.

${ }^{39}$ Tamże III 115e. Na temat tego sposobu pieczenia zob. Alcock, Food in the Ancient World, s. 108.

${ }^{40}$ Athenaeus, Deipnosophistae III 113a.

${ }^{41}$ Plinius, Historia naturalis XVIII 27, 105.

${ }^{42}$ Athenaeus, Deipnosophistae III 115e.

${ }^{43}$ Hippocrates, De diaeta II 42, 19; w niniejszym opracowaniu posługiwano się wydaniem: Hippocratis De diaeta, edidit, in linguam francogallicam vertit, comentatus est R. Joly, adiuvante S. Byl, Berlin 2003. Zgodnie z inną etymologią chleb nazwano w ten sposób, ponieważ kosztował obola, por. Athenaeus, Deipnosophistae III 111b.

${ }^{44}$ Athenaeus, Deipnosophistae III 109c.

${ }^{45}$ Plinius, Historia naturalis XVIII 27, 105.

${ }^{46}$ Athenaeus, Deipnosophistae III 110b-c.

${ }^{47}$ Plinius, Historia naturalis XVIII 27, 105.

${ }^{48}$ Por. Publius Ovidius Naso, Fasti VI 315-316; w niniejszym opracowaniu posługiwano się wydaniem: Ovid's Fasti, with an English Translation by Sir J.G. Frazer, London - Cambridge Mass. 1959; R.I. Cutris, Ancient Food Technology, Leiden - Boston - Köln 2001, 368.

${ }^{49}$ Por. Alcock, Food in the Ancient World, s. 108.

${ }^{50}$ Piece tego rodzaju mogły służyć również do pieczenia mięs, zarówno w całości jak i porcjowanych, por. Apicius, De re coquinaria VIII 6, 10; VII 4, 1, 2; w niniejszym opracowaniu 
nia $^{51}$, cegły ${ }^{52}$, gliny ${ }^{53}$ lub żelaza ${ }^{54}$. Piec o kształcie kopuły wznoszono na ceglanym lub kamiennym postumencie, czasem obudowywano dodatkowo cegłą, dzięki czemu dłużej utrzymywał ciepło ${ }^{55}$. Konstrukcja ta sięgała do samego sufitu pomieszczenia, w którym się znajdowała, ułatwiając wentylację, która odbywała się przez otwór $\mathrm{w}$ dachu lub przewód kominowy ${ }^{56}$. Wewnątrz pieca rozpalano ogień, który nadawał komorze odpowiednio wysoką temperaturę. Gdy urządzenie było wystarczająco gorące usuwano z niego żar. Następnie, przy pomocy łopaty piekarskiej ${ }^{57}$ uformowane bochenki wsuwano do wnętrza pieca. Zachowywano przy tym odpowiednią kolejność, by każdy rodzaj wypiekał się w optymalnych dla siebie warunkach. Jako pierwsze pieczono chleby najcieńsze lub nie zawierające zakwasu ${ }^{58}$. Później w środku urządzenia umieszczano resztę pieczywa, większe bochenki w najcieplejszym obszarze, mniejsze - bliżej środka ${ }^{59}$. Aby wypieki nie były zbyt suche piekarz skrapiał wnętrze komory pieca wodą ${ }^{60}$. Ostatnim etapem było zamknięcie drzwiczek ${ }^{61}$. $\mathrm{W}$ tego rodzaju urządzeniu chleb piekł się około godziny ${ }^{62}$. Prostszą budową charakteryzował się, przeznaczony do wypieku pojedynczych bochenków furniculus. Był to nieduży piec składający się jedynie z paleniska pokrytego cienkim sklepieniem $\mathrm{z}$ otworem służącym do wsuwania do środka mających upiec się produktów.

Odpowiednikiem pieca typu furnus był grecki i $\pi v o ́ \varsigma^{63}$. Być może jego konstrukcja nie zawsze idealnie odpowiadała rzymskiej instalacji. Brian A. Sparkes twierdzi, że i $\pi v o ́ \varsigma$ nie przypominał wyglądem opisanych wyżej urządzeń. Jego zdaniem był to przenośny przyrząd niedużych rozmiarów, składający się z płytkiego paleniska osadzonego na czterech nóżkach, nad nim miała znajdować się komora pieca. Szczeliny mieszczące się między jej podstawą a górną częścią paleniska umożliwiały dostęp tlenu, niezbędnego do utrzyma-

posługiwano się wydaniem: Apicius, A Critical Edition with an Introduction and an English Translation of the Latin Recipe Text Apicius, Text and Commentary Ch. Grocock - S. Grainger, Totnes 2006; tłum. I. Mikołajczyk - S. Wyszomirski: Apicjusz, O sztuce kulinarnej ksiag dziesięć, Toruń 1998.

${ }^{51}$ Por. P. Faas, Around the Roman Table, trans. S. Whiteside, Chicago - London 2005, 132.

${ }^{52}$ Por. tamże.

${ }^{53}$ Por. Alcock, Food in the Ancient World, s. 108.

${ }^{54}$ Por. tamże.

${ }^{55}$ Por. Cutris, Ancient Food Technology, s. 366; Thurmond, A Handbook of Food Processing, s. $68-69$.

${ }^{56}$ Por. Cutris, Ancient Food Technology, s. 366; Thurmond, A Handbook of Food Processing, s. 69 (rysunek przekroju pieca, tamże, s. 70).

${ }^{57}$ Por. Cutris, Ancient Food Technology, s. 366; Thurmond, A Handbook of Food Processing, s. 69.

${ }^{58}$ Por. Faas, Around the Roman Table, s. 132.

${ }^{59}$ Por. Thurmond, A Handbook of Food Processing, s. 69.

${ }^{60}$ Por. tamże, s. 71.

${ }^{61}$ Por. tamże; Faas, Around the Roman Table, s. 132.

${ }^{62}$ Por. Thurmond, A Handbook of Food Processing, s. 71; Faas, Around the Roman Table, s. 132.

${ }^{63}$ Por. Dalby, Food, s. 101-102. 
nia żaru. Źródło ciepła mieściło się więc niemal bezpośrednio pod piekącym się bochenkiem ${ }^{64}$.

Ze względu na swoje niewielkie rozmiary najpopularniejszym urządzeniem służącym do pieczenia, nie tylko chleba, ale też ciast, czy mięs był przenośny piekarnik. Określano go kilkoma terminami: łacińskim testum lub

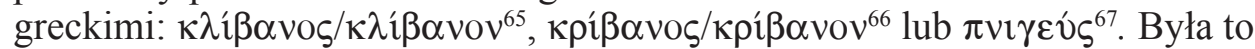
pokrywka wykonana z brązu, żelaza lub gliny ${ }^{68}$ o kształcie spłaszczonej kopuły, pod którą umieszczano mającą upiec się potrawę. Stąd łacińska nazwa tego sposobu pieczenia: sub testu - pod pokrywką. Najpierw rozpalano ogień, nad nim wieszano pokrywę, by mogła się rozgrzać. Potem usuwano popiół i na oczyszczonym palenisku kładziono pożywienie, które zakrywano testum. Aby utrzymać wysoką i równomierną temperaturę we wnętrzu piekarnika obkładano go rozżarzonym węglem drzewnym ${ }^{69}$. Na szczycie niektórych urządzeń mógł widnieć otwór, na którym umieszczona była ruchoma gałka, unosząc ją można było kontrolować stopień upieczenia potrawy ${ }^{70}$. Jednak nie wszystkie przyrządy były w nią wyposażone. W takim wypadku, by sprawdzić, czy danie jest już gotowe należało podnieść całą pokrywkę $e^{71}$.

Sposób, w jaki wytwarzano pieczywo, nie był bez znaczenia dla zdrowia i samopoczucia konsumenta. Zdaniem Galena najlepsze są chleby z przenośnego piekarnika ${ }^{72}$. Opinię tę podziela, cytowany przez Atenajosa, Filistion z Lokroi, który twierdzi, że tego rodzaju pieczywo jest aromatyczne, zdrowe a przy tym lekkostrawne - nie powoduje wzdęć ani zablokowania żołądka ${ }^{73}$. Ojciec medycyny, Hipokrates, uważa natomiast, że tego rodzaju wypiek jest najbardziej suchy ${ }^{74}$. Drugie w kolejności, zdaniem medyka z Pergamonu, są

${ }^{64}$ Opis urządzenia i rysunek w: Sparkes, The Greek Kitchen, s. 127-128.

${ }^{65}$ Por. Dalby, Food, s. 101.

${ }^{66}$ Aristophanes, Vespae 1153; w niniejszym opracowaniu posługiwano się wydaniem: Aristophanes, The Acharnians, The Knights, The Clouds, The Wasps, with the English Translation of B.B. Rogers, I, London - Cambridge Mass. 1967, 404-549; Athenaeus, Deipnosophistae III 110c.

${ }^{67}$ Por. Sparkes, The Greek Kitchen, s. 128.

${ }^{68} \mathrm{~W}$ takim wypadku glina zmieszana była z piaskiem i drobinami potłuczonej ceramiki, by uchronić pokrywę przed pęknięciem grożącym przy kontakcie z gorącymi węglami. Por. A. Dalby - S. Grainger, The Classical Cookbook, London 2000, 18; Sparkes, The Greek Kitchen, s. 124; A. Cubberley, Bread - Baking in Ancient Italy. Clibanus and Sub Testu in the Roman World: Further Thoughts, w: Food in Antiquity, ed. J. Wilkins, D. Harvey, M. Dobson, Exeter 1999, 58.

${ }^{69}$ Por. Ch. Grocock - S. Grainger, Introduction, w: Apicius, s. 82. Zob. Dalby - Grainger, The Classical Cookbook, s. 18; Dalby, Food, s. 101; Alcock, Food in the Ancient World, s. 108; Sparkes, The Greek Kitchen, s. 128.

${ }^{70}$ Grocock - Grainger, Introduction, s. 82.

${ }^{71}$ Por. Cato Marcius Porcius, De agri cultura LXXVI 4.

${ }^{72}$ Por. Galenus, De alimentorum facultatibus lib. 489, 6-8.

${ }^{73}$ Por. Athenaeus, Deipnosophistae III 115e.

${ }^{74}$ Por. Hippocrates, De diaeta II 42, 20-21. Przypisywanie rzeczonego traktatu Hipokratesowi jest oczywiście jedynie symboliczne. Na temat samego Hipokratesa oraz Corpus Hippocraticum, por. V. Nutton, Ancient Medicine, London - New York 2007, 53-71. 
wypieki pochodzące z pieca i $\pi v o ́ s$, pod warunkiem, że zostały one odpowiednio upieczone ${ }^{75}$. Hipokrates chwali pożywność tych wypieków ${ }^{76}$, Filistion natomiast uważa je za niestrawne i trudno przyswajalne ${ }^{77}$. Klasyfikuje on nadto

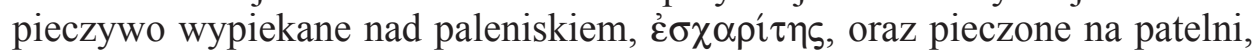

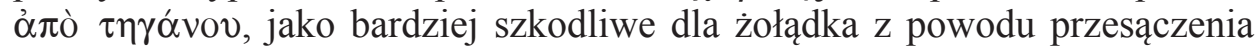
parą, ale łatwiejsze $\mathrm{w}$ wydalaniu, dzięki domieszce oliwy ${ }^{78}$. Za najgorszą

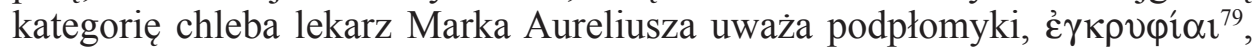
pisząc, że są nierówno wypieczone ${ }^{80}$, z tego powodu określa je jako ciężkie i niestrawne ${ }^{81}$.

Osoby dobrze sytuowane, oprócz pieczywa, mogły sobie pozwolić na wypiek ciast, chociażby takich jak placki o nazwie libum $^{82}$. Słowo to pochodzi od łacińskiego czasownika libare oznaczającego składanie ofiary bogom ${ }^{83}$, co podkreśla „sakralną” tradycję ${ }^{84}$ tego dania. Z przekazu Owidiusza wynika, że ciasto to, przygotowane (również) z mąki jaglanej, poświęcone było Weście ${ }^{85}$. $\mathrm{Z}$ czasem zaczęto traktować je jednak jak zwykły, słodki placek ${ }^{86}$, na który przepis zachował się w De agricultura Katona. Wymienia on wprawdzie, zamiast mąki z prosa, mąkę pszenną, ale możemy przypuszczać, że pozostałe składniki stanowiły podstawę potrawy. Aby ją przygotować należało utrzeć w moździerzu dwa funty ${ }^{87}$ sera, później dosypać funt pszenicznej mąki (siligo) lub, dla lepszego efektu, pół funta mąki similago otrzymywanej z tego samego zboża. Do tego wbijano jedno jajko i całość dokładnie łączono z serem. Powstałe w ten sposób ciasto formowano w kształcie bochenka, układano na

\footnotetext{
${ }^{75}$ Por. Galenus, De alimentorum facultatibus lib. 489, 10-11.

${ }^{76}$ Jego zdaniem były one bardziej odżywcze niż chleby wypiekane nad paleniskiem i na rożnie, z powodu mniejszego stopnia przypalenia, zob. Hippocrates, De diaeta II 42, 18-20.

${ }^{77}$ Por. Athenaeus, Deipnosophistae III 115e.

${ }^{78}$ Tamże.

${ }^{79}$ Hipokrates stawiał chleb upieczony w ten sposób na równi z pieczywem z przenośnego piekarnika uważał je za najbardziej suchy gatunek pieczywa, por. Hippocrates, De diaeta II 42, 20-21.

${ }^{80}$ Por. Galenus, De alimentorum facultatibus lib. 489, 15 - 490, 3.

${ }^{81}$ Por. Athenaeus, Deipnosophistae III 115e.

${ }^{82}$ Publius Ovidius Naso, Fasti IV 743; por. P. Berdowski, Przysmaki Katona, czyli o najstarszych przepisach kulinarnych Rzymian, „Nowy Filomata” 3 (1998) 175.

${ }^{83}$ Por. Plezia III 356-357; Berdowski, Przysmaki Katona, s. 175.

${ }^{84}$ Por. Publius Ovidius Naso, Fasti I 127-128; III, 761; IV, 743-744; Quintus Horacius Flaccus, Epistula X 10; w niniejszym opracowaniu posługiwano się wydaniem: Horace, Satires, Epistles and Ars Poetica, with an English Translation by H.R. Fairclough, London - Cambridge Mass. 1961, 248-441.

${ }^{85}$ Por. Publius Ovidius Naso, Fasti IV 743-744. Z treści źródeł wynika, że z prosa wytwarzano też kaszę fitilla, poświęcaną bóstwom, zob. Arnobius, Adversus nationes lib. II 21; w niniejszym opracowaniu posługiwano się wydaniem: Arnobii Adversus nationes libri VII, recensuit et commentario critico instruxit A. Reifferscheid, Vindobonae 1875; André, L'alimentation, s. 63.

${ }^{86}$ Por. Quintus Horacius Flaccus, Satirae II 7, 102; w niniejszym opracowaniu posługiwano się wydaniem: Horace, Satires, Epistles and Ars Poetica, s. 2-245; Athenaeus, Deipnosophistae III 125f-126a.

${ }^{87}$ Funt $=27,3 \mathrm{~g}$.
} 
liściach $^{88}$ i pieczono sub testu ${ }^{89}$. Wraz z upowszechnieniem się dania zaczęto dodawać do niego nowe komponenty jak miód ${ }^{90}$, czy mleko ${ }^{91}$.

Pieczywo (słodkie i nie) w starożytności oraz w czasach bizantyńskich, ze względu na wysoką cenę oraz czasochłonność procesu jego wykonania, było często nieosiągalne dla znacznej części społeczeństwa. Brak chleba uboższa część ludności zamieszkująca obszar basenu Morza Śródziemnego rekompensowała sobie jego substytutami. Były nimi grecka $\mu \hat{\alpha} \zeta \alpha$ i rzymska puls. Obie potrawy przygotowywane były z roślin typowych dla danego regionu. Wśród zbóż w Grecji były to najczęściej jęczmień i pszenica, a w Italii, przed pojawieniem się tych gatunków - orkisz, żyto i proso zwyczajne ${ }^{92}$. Mấ $\alpha$ powstawała przez wyrobienie mąki z płynami, bez poddania tak powstałej masy żadnej obróbce termicznej. Właśnie taki pokarm przygotowany (również) z mąki ${ }^{93}$ uzyskanej z prosa ${ }^{94}$, a wyrobionej z wodą (ale także $\mathrm{z}$ winem i moszczem winnym ${ }^{95}$ ), opisuje w swoim traktacie Galen ${ }^{96}$. Tradycja przyrządzania $\mu \widehat{\alpha} \zeta \alpha$ poświadczona jest na wiele stuleci przed czasami medyka z Pergamonu. Wiemy o tym choćby dzięki faktowi, iż w swych traktatach powołał się on na ustalenia swych słynnych poprzedników, mianowicie Filotimosa (IV-III w.) i jego nauczyciela Praksagorasa (IV w. przed Chr.) ${ }^{97}$. Warto dodać, że jedną z pierwszych wzmianek o tej potrawie odnajdujemy już w Pracach $i$ dniach ${ }^{98}$ Hezjoda. Puls natomiast była ${ }^{99}$ gotowaną bryją, która w typowo rolniczym państwie, jakim w epoce archaicznej był Rzym, urosła do rangi narodowej potrawy. Warron w De lingua latina podaje dwie wersje etymologii łacińskiej nazwy posiłku. Mieli nadać ją Grecy (a zatem termin puls byłby równoznacz-

${ }^{88}$ Katon nie precyzuje gatunku rośliny, z której liście miały pochodzić. Sądzimy, że charakteryzowały się one zapachem, który podczas pieczenia nadawał ciastu specyficzny aromat. Zabieg ten stosowany był na przykład podczas przygotowania mustacei, zob. Cato Marcius Porcius, De agri cultura CXXI.

${ }^{89}$ Cato Marcius Porcius, De agri cultura LXXV. Współczesne wersje tego przepisu, zob. Dalby - Grainger, The Classical Cookbook, s. 92-94; M. Grant, Roman Coockery. Ancient Recipes for Modern Kitchens, London 2002, 59-60.

${ }^{90}$ Por. Publius Ovidius Naso, Fasti III 761-762.

${ }^{91}$ Por. Athenaeus, Deipnosophistae III 125f-126a. Zob. Berdowski, Przysmaki Katona, s. 175.

${ }^{92}$ Por. Winniczuk, Chleb u starożytnych, s. 232.

${ }^{93}$ Fakt, że Galen przedstawia proso i włośnicę jako pokarm ubogich sugeruje, że zapewne była to mąka gruba, przypominająca kaszę.

${ }^{94}$ Por. Galenus, De alimentorum facultatibus lib. 510, 8.

${ }^{95}$ Por. tamże 510, 2-3.

${ }^{96}$ Zapewne po to, by uzyskać potrawę podobną do zwykłej, jęczmiennej $\mu \hat{\alpha} \zeta \alpha$, zob. Galenus, De alimentorum facultatibus lib. 510, 6-11.

${ }^{97}$ Por. Galenus, De alimentorum facultatibus lib. 509, 14-16.

${ }^{98}$ Por. Hesiodus, Opera et dies 590; w niniejszym opracowaniu posługiwano się wydaniem: The Homeric Hymns and Homerica, with an English Translation by H.G. Evelyn-White, London Cambridge Mass. 1959, 2-65.

${ }^{99}$ Puls, pultis w języku łacińskim jest rodzaju żeńskiego, dlatego będziemy posługiwać się nim $\mathrm{w}$ tej formie w dalszej części artykułu. Zob. Plezia IV 385. 
ny z greckim $\pi$ ó $\lambda \tau o \varsigma)^{100}$ lub, zgodnie z przekazem Apollodorusa, termin ten miał charakter onomatopeiczny, gdyż przypominał dźwięk, jaki wydaje mąka/ kasza wrzucana do wody ${ }^{101}$. O powszechności i długiej tradycji przygotowywania tego dania na terenie antycznej Italii świadczą wzmianki w literaturze. Warron stwierdzi, że puls jest najstarszą spośród potraw ${ }^{102}$. Słowa te potwierdza Pliniusz pisząc, że Rzymianie przez długi czas żywili się nie chlebem, lecz $p_{u l s}{ }^{103}$. Plaut, z kolei $\mathrm{w}$ jednej z komedii, robiąc aluzję do swego italskiego pochodzenia, nazywa siebie Plautus Pultifagonides - Plaut Papkojadacz ${ }^{104}$. Danie to spożywane było przez cały okres istnienia Imperium Romanum również w kręgach wojskowych, gdzie stanowiło ważny element diety legionistów ${ }^{105}$. Sytuacja nie uległa zmianie w czasach Cesarstwa Bizantyńskiego, kiedy to w skład prowiantu żołnierzy wchodziła między innymi puls przygotowywana z kaszy jaglanej nazywana $\pi \dot{\imath} \sigma \tau o v^{106}$. Być może o popularności tej potrawy w warunkach polowych zadecydowała wydajność, ponieważ, jak informuje nas Pliniusz, po namoczeniu trzech szesnastych modiusa ${ }^{107}$ mąki/kaszy jaglanej w wodzie otrzymywano jeden modius puls ${ }^{108}$. Ten rodzaj jedzenia przyrządzony z opisywanego zboża, znany był również wśród ludu Sarmatów. Mieli oni nieoczyszczoną (razową) mąkę z prosa łączyć z mlekiem klaczy lub $\mathrm{z}$ krwią upuszczoną z końskiej nogi ${ }^{109}$.

${ }^{100}$ Greckie pochodzenie słowa puls od $\pi$ ó $\tau$ oৎ nie zostało jednak poświadczone. Por. Plezia IV 385; Marcus Terentius Varro, De lingua latina V 22, 105; ed. Varro, On the Latin language, with an Engish Translation by R.G. Kent, I, London - Cambridge Mass. 1958, 100, nota $a$. Tezę tę zdaje się potwierdzać Pliniusz (Historia naturalis XVIII 19, 84, ed. Rackham): „Videturque tam puls ignota Graeciae fuisse quam Italiae polenta (zdaje się, że puls była nieznana w Grecji, tak jak w Italii polenta)".

${ }^{101}$ Por. Marcus Terentius Varro, De lingua latina V 22, 105.

${ }^{102}$ Por. tamże, ed. Kent, I, s. 100: „De victu antiquissima puls”.

${ }^{103}$ Por. Plinius, Historia naturalis XVIII 19, 83-84, ed. Rackham: „Pulte autem, non pane, vixisse longo tempore Romanos manifestum [...]”. W dalszej części zdania autor wyjaśnia, że do czasów mu współczesnych pożywienie określa się terminem pulmentaria.

${ }^{104}$ Titus Maccius Plautus, Pseudolus 54, ed. Plautus, with an English Translation by P. Nixon in Five Volumes, IV, London - Cambridge Mass. 1959, 6. W innym utworze autor użył zwrotu: ,pultiphagus opifex barbarus (barbarzyński twórca papkojadacz)" (Titus Maccius Plautus, Mostellaria 828, ed. Nixon, III, London - Cambridge Mass. 1957, 374.

${ }^{105}$ Por. Winniczuk, Chleb u starożytnych, s. 232-233; Berdowski, Przysmaki Katona, s. 179. Tego typu pożywienie było zapewne w warunkach polowych znacznie łatwiejsze w przygotowaniu niż wypiekanie chleba, zob. T. Braun, Barley Cakces and Emmer Bread, w: Food in Antiquity, s. 36.

${ }^{106}$ Forma $\pi$ í $\sigma \tau$ ov znana nam jest z ustaleń Andrew Dalby'ego (Siren Feasts. A History of Food and Gastronomy in Greece, London - New York 1996, 197). Sami jednak nie natrafiliśmy na

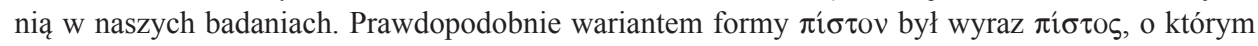

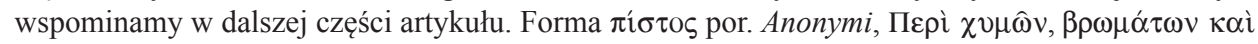
$\pi \mathrm{o}$ ó $\tau \omega v$ 32, 1-2, ed. I.L. Ideler w: Physici et medici Graeci minores, II, Amsterdam 1963, 270.

${ }^{107}$ Modius $=8,751$.

${ }^{108}$ Por. Plinius, Historia naturalis XVIII 10, 54-55.

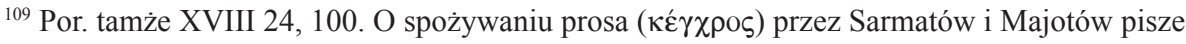
też Klaudiusz Elian (Varia historia III 39, 3). 
Dużej popularności różnych odmian puls zawdzięczamy kilka wariacji przepisów nań zachowanych w literaturze medycznej, gastronomicznej i agronomicznej. Kasza z prosa jednak wymagana jest w nich tylko sporadycznie. Mimo to możemy być pewni, że wykorzystywano ją w tym celu częściej niż zaświadczają zachowane źródła, zwłaszcza na terenach odpowiednich do uprawy opisywanego zboża, jak Kampania, gdzie przygotowywano z prosa puls charakteryzującą się białym kolorem ${ }^{110}$. Barwa tej potrawy zapewne uwarunkowana była jasnym odcieniem użytej kaszy. Wnioskować tak można, gdyż Hesychiusz utrzymywał, iż produkt ten otrzymywany z prosa odznaczał się białością, to znaczy, że do kaszy typu ${ }^{\prime} \lambda \varphi \imath \tau \alpha$ z prosa pasował epitet „biała” $(\lambda \varepsilon v \kappa \alpha){ }^{111}$. Możliwe również, że omawiany produkt gotowano $\mathrm{z}$ dodatkiem mleka, co z pewnością dodatkowo go rozbielało. W większości zachowanych stricte kulinarnych receptur zboże to jest jedynie wzmiankowane jako substytut kaszy pszenicznej lub orkiszowej. Dlatego też, chcąc przybliżyć sposoby przygotowania puls, odwoływać będziemy się do analogicznych receptur z wykorzystaniem ziaren innych gatunków. Datowana na IV w. kompilacja łacińskich przepisów znana pod tytułem De re coquinaria, zawiera między innymi przepisy na słone pultes $-\mathrm{z}$ dodatkiem mięsa i przypraw.

Na przykład, aby przyrządzić potrawę à la Julianus namoczoną kaszę z orkiszu należało gotować tak długo aż napęcznieje. Następnie dodawano do niej oliwę i po zgęstnieniu całość dokładnie rozcierano. Osobno przygotowywano mięso - w moździerzu ucierano dwa gotowane móżdżki i pół libry $y^{112}$ drobno posiekanego mięsa. Po przełożeniu do garnka doprawiano je pieprzem, lubczykiem ogrodowym, nasionami kopru włoskiego, sosem ze sfermentowanych ryb (liqamen), niewielką ilością wina i gotowano. Po wymieszaniu tak powstałego sosu wraz z mięsem, stopniowo łączono otrzymaną masę z kaszą, za każdym razem rozcierając całość, tak, by potrawa przypominała papkę ${ }^{113}$. Puls przygotowaną według tej receptury, ze względu na nietanie składniki (mięso, sos rybny, pieprz), podawano zapewne na stołach zamożniejszych osób. Natomiast ubożsi musieli zadowolić się skromniejszą o wykwintne komponenty wersją posiłku. Gotowali oni kaszę jaglaną z dodatkiem tłuszczu wieprzowego lub oliwy ${ }^{114}$. Znane były też pultes przygotowywane „na słodko", w tym przypadku również dysponujemy kilkoma przepisami. Katon

${ }^{110}$ Por. Plinius, Historia naturalis XVIII 24, 100.

111 Barwę taką odznaczała się produkowana z prosa kasza typu ö $\lambda \varphi \imath \tau \alpha$, zob. Hesychius

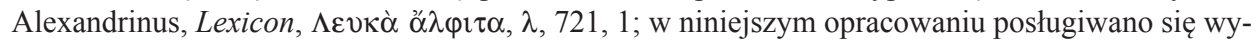
daniem: M. Schmidt: Hesychii Alexandrini Lexicon, I-V, Ienae 1858-1868.

${ }^{112}$ Libra $=327,4 \mathrm{~g}$.

${ }^{113}$ Por. Apicius, De re coquinaria V 1, 1. W opusculum znajduje się jeszcze jeden przepis wymagający bez mała tych samych składników. Wyjątek stanowi czyste wino, zob. Apicius, De re coquinaria $\mathrm{V} 1$, 4. Na temat powiązań między sztuką kulinarną i medycyną w De re coquinaria por. M. Kokoszko - Z. Rzeźnicka - K. Jagusiak, Health and Culinary Art in Antiquity and Byzantium in the Light of ,De re coquinaria”, „Studia Ceranea” 2 (2012) 145-164.

${ }^{114}$ Por. Galenus, De alimentorum facultatibus lib. 523, 9 - 524, 10. 
W recepturze na puls punica radzi dodać do naczynia, w którym znajduje się namoczona w wodzie do miękkości kasza orkiszowa, trzy funty świeżego sera, pół funta miodu i jedno jajko. Całość, po dokładnym wymieszaniu, należało przełożyć do nowego garnka ${ }^{115}$. W nim prawdopodobnie potrawę podgrzewano, mieszając, by się nie przypaliła. Marek Porcjusz w treści swojej receptury pomija ten etap przyrządzania potrawy, ponieważ, prawdopodobnie, uznał go za zbyt oczywisty. Inny sposób przygotowania słodkiego puls to tzw. pultes tractogalatae $^{116}$, czyli zacierki z płatów ususzonego ciasta - tracta ${ }^{117}$ oraz mleka. Zgodnie z zapiskami anonimowego autora trzy płaty wkruszonego, cienkiego ciasta należało ugotować w sextariusie ${ }^{118}$ mleka z dodatkiem niedużej ilości wody. Całość mieszano, by się nie przypaliła. Po ugotowaniu, gdy garnek znajdował się jeszcze na ogniu, dodawano miód. Podobnie postępowano przygotowując pultes z chlebków upieczonych na moszczu winnym ${ }^{119}$. Różnica polegała jedynie na dodaniu do potrawy soli i oliwy ${ }^{120}$.

Ostatnie dwa przepisy są dla nas szczególnie ważne, ze względu na obecność w nich mleka. $Z$ treści zachowanych źródeł możemy wnioskować, że kasza/mąka z prosa wyjątkowo dobrze komponowała się z tym płynem ${ }^{121}$. Zapiski zawarte w traktatach medycznych sugerują, że połączenie obu składników nie było powodowane wyłącznie walorami smakowymi, ale i zdrowotnymi. Z informacji pozostawionych przez Galena w De rebus boni malique suci, dowiadujemy się, że mąkę jaglaną typu ở $\lambda \varepsilon v \rho v^{122}$ dodawano do gotującego

${ }^{115}$ Por. Cato Marcius Porcius, De agri cultura LXXXV. Zob. Berdowski, Przysmaki Katona, s. 179. Współczesna wersja przepisu, zob. Grant, Roman Coockery, s. 39.

${ }^{116}$ Apicius, De re coquinaria $\mathrm{V} 1,3$.

${ }^{117}$ Przepis na tracta, zob. Cato Marcius Porcius, De agri cultura LXXVI 1-2. Smakołyk wspomniany jest też w Deipnosofistach Atenajosa (III 113 d). O tym rodzaju ciasta pisali np. J. Solomon, Tracta: A Versatile Roman Pastry, „Hermes” 106 (1978) 539-556; S. Hill - A. Bryer, Byzantine Porridge Tracta, Trachanás and Trahana, w: Food in Antiquity, 44-54.

${ }^{118}$ Sextarius $=0,541$.

${ }^{119}$ Mustacei, na które przepis zamieszczony został w De agricultura Katona (CXXI). Współczesna wersja przepisu, zob. Grant, Roman Coockery, s. 109-111.

${ }^{120}$ Por. Apicius, De re coquinaria V 1, 3: „Ex musteis cum lacte similiter facies, salem et oleum minus mittis". Pojawiający się w tekście zwrot: salem et oleum minus mittis polscy thumacze przetłumaczyli dosłownie, czyli „dodasz mniej soli i oliwy”. Takie wyrażenie w kontekście treści całej receptury jest nielogiczne, ponieważ jej autor, nie wspomina o doprawieniu potrawy solą i oliwą. Przyjęliśmy więc przekład jaki proponują brytyjscy tłumacze De re coquinaria. Doszli oni do wniosku, że prawdopodobnie kucharz powinien dodać soli i oliwy w ilości mniejszej niż zwykle zob. Apicius, s. 207, nota 3.

${ }^{121}$ Por. Galenus, De alimentorum facultatibus lib. 523, 9 - 524, 10; Columella, Res rustica II 9, 19; Anthimus, De observatione ciborum 71; w niniejszym opracowaniu posługiwano się wydaniem: Anthimi De observatione ciborum (Ad Theodoricum regem Francorum epistula), ed. E. Liechtenhan, Berolini 1963.

${ }^{122} \mathrm{O}$ wytwarzaniu mąki ở $\lambda \varepsilon v \rho o v$ z prosa pisze również Aecjusz z Amidy (Iatricorum lib. VI 47, 13-16; w niniejszym opracowaniu posługiwano się wydaniem: Aetii Amideni Libri medicinales I-VIII, ed. A. Olivieri, I-II, Lipsiae - Berolini 1935-1950). Praktyka ta była powszechna jeszcze w X 
się mleka ${ }^{123} \mathrm{w}$ celu poprawienia jego właściwości ${ }^{124}$. Zabieg ten stosowany był również przez kolejne stulecia, a wzmianki o nim znajdujemy w dziele żyjącego na przełomie VI i VII w. Aleksandra $\mathrm{z}$ Tralles ${ }^{125}$ oraz w jedenastowiecznym Syntagma de alimentorum facultatibus Symeona Setha, który pisze o swego rodzaju zupie mlecznej przygotowywanej z dodatkiem włośnicy i prosa ${ }^{126}$. Być może miał on na myśli danie, zalecane osobom cierpiącym na dyzenterię, na które recepturę zanotował Antimus ${ }^{127}$ - lekarz żyjący w VI w. Zgodnie z jego wskazówkami zboże najpierw należało ugotować w świeżej, gorącej wodzie. Gdy nasiona zaczynały pękać, otwierając się, dodawano do nich kozie mleko. Ważne było, by robić to powoli i dokładnie, ponieważ uważano, że twarda i niedogotowana kasza, podobnie jak ryż ${ }^{128}$ podany w tej postaci, ma szkodliwe działanie na ludzki organizm. Danie przygotowane zgodnie z powyższym przepisem było skutecznym lekarstwem na jedną z najbardziej rozpowszechnionych chorób epoki antyku. Konsumpcja tego przysmaku, dzięki ściągającym właściwościom prosa, zapobiegała uporczywym biegunkom będących objawem infekcji gastrycznych. Warto też dodać, że podobny przepis, tym razem z wykorzystaniem mąki pszennej, zachował się w De agricultura Katona $^{129}$. Istnieje jednak przecież prawdopodobieństwo, że w czasach nieurodzaju tego ostatniego zboża danie przyrządzano również z mąki jaglanej. Aby uwarzyć rzeczoną potrawę, należało utrzeć w moździerzu pół funta czystej pszenicy. Oczyszczoną z plew mąkę gotowano w dobrej wodzie. Po zagotowaniu stopniowo dolewano mleko, do momentu powstania gęstego kleiku ${ }^{130}$.

Sporo informacji na temat wariantów recepturalnych gęstych zup z dodatkiem mleka dostarczył Galen, na przykład w De alimentorum facultatibus. Lekarz utrzymywał, że pracujący na polach wytwarzają z prosa i włośnicy

stuleciu. Autor Geoponik (IV 15, 9) zaznacza, że mąka ta miała nie tylko zastosowanie spożywcze. Wykorzystywana była jako środek konserwujący kiście winogron. Zgodnie z bizantyńską literaturą leksykograficzną drobno mielona mąka ở $\lambda \varepsilon v \rho o v$ wyprodukowana z jęczmienia lub prosa nazy-

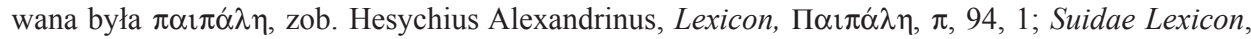

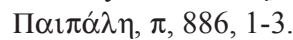

${ }^{123}$ Por. Galenus, De rebus boni malique suci libellum 767, 14-16; w niniejszym opracowaniu posługiwano się wydaniem: G. Helmreich, w: Galeni De sanitate tuenda libri VI, De alimentorum facultatibus libri III, De bonis malisque sucis liber, De victu attenuante liber, De ptisana liber, Lipsiae - Berolini 1923, 387-429.

${ }^{124}$ Por. Galenus, De rebus boni malique suci 767, 11-16.

${ }^{125}$ Por. Alexander Trallianus, Therapeutica II 209, 27; w niniejszym opracowaniu posługiwano się wydaniem: Alexander von Tralles: Original-Text und Übersetzung nebst einer einleitenden Abhandlung: Ein Beitrag zur Geschichte der Medicin, I-II, Vienna 1878-1979 (reprint: Amsterdam 1963).

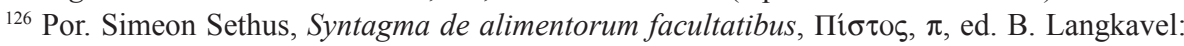
Simeonis Sethi Syntagma de alimentorum facultatibus, Lipsiae 1868, 87.

${ }^{127}$ Anthimus, De obseruatione ciborum 71.

${ }^{128}$ Tamże 70.

${ }^{129}$ Zmodernizowany przepis, zob. Grant, Roman Coockery, s. 40-41.

${ }^{130}$ Por. Cato Marcius Porcius, De agri cultura LXXXVI. Zob. Berdowski, Przysmaki Katona, s. $179-180$. 
mąkę ö $\lambda \varepsilon v \rho o v$, a dodając do niej wieprzowy tłuszcz lub oliwę ${ }^{131}$, przygotowują posiłek podobny do tego sporządzanego ze zwykłej, pszenicznej mąki ó $\lambda \varepsilon v \rho o v$. Ten sam temat podejmuje w De rebus boni malique suci, gdzie

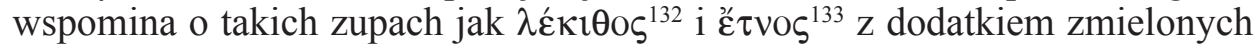
ziaren interesujących nas zbóż. Ich przygotowanie wymagało lepkich komponentów nadających potrawie spoistości jak tłuszcz pochodzenia zwierzęcego (smalec wieprzowy, łój kozi) lub roślinnego (oliwa), a równie ważnym składnikiem było owcze lub krowie mleko ${ }^{134}$. Autor wspomina, że takie dania konsumowane były podczas prac polowych ${ }^{135}$, możemy zatem przypuszczać, że należały one ex definitione do kategorii prostych w przygotowaniu, niewyszukanych i tanich.

Pragniemy zwrócić uwagę, że dane uzyskane od Katona oraz informacje z przytoczonych prac medycznych prowadzą do konkluzji, iż tradycja przygotowywania gęstych zup/papek z mąki czy kaszy (w tym również mąki oraz kaszy jaglanej) z dodatkiem mleka zakorzeniona była na terenach śródziemnomorskich już na przełomie III i II w., czyli na kilkaset lat przed powstaniem pism Galena, nie mówiąc już o dacie spisania wspomnianych powyżej bizantyńskich traktatów medycznych. Prawdopodobnie za Katona Starszego, a nawet i znaczniej wcześniej, pokarm taki pełnił rolę zwykłego, codziennego posiłku, który - co potem uwypuklono i utrwalono w tradycji dietetycznej antyku i Bizancjum - jednocześnie zapobiegał powstawaniu i rozwojowi chorób układu pokarmowego, a zwłaszcza dyzenterii.

Inne dane prowadzą nas do wniosku, iż zaprezentowaną wyżej generalną konkluzję rozciągnąć można także na inne potrawy z gotowanego prosa. Пó $\lambda \tau$ z użyciem kaszy/mąki jaglanej, ale tym razem już bez dodatku mleka, znajdujemy zarówno w dziełach Dioskuridesa ${ }^{136}$, medyka epoki antyku, jak i wczesnośredniowiecznych lekarzy, to znaczy Aecjusza z Amidy ${ }^{137}$ i Aleksandra $\mathrm{z}$ Tralles ${ }^{138}$. Zdaniem tego ostatniego $\pi$ ó $\lambda \tau$ or z prosa usuwały nadmiar wilgo$\mathrm{ci}^{139} \mathrm{z}$ jamy brzusznej i były nawet bardziej efektywne niż analogiczne potrawy przygotowywane z ryżu ${ }^{140}$. Dwa sposoby przygotowania tego typu potraw

\footnotetext{
${ }^{131}$ Por. Galenus, De alimentorum facultatibus lib. 523, 14-15.

${ }^{132} \Lambda \varepsilon ́ \kappa 1 \theta 0 \varsigma$ przyrządza się z ở $\lambda \varepsilon v \rho o v$ z dodatkiem tłuszczu, por. Galenus, De rebus boni malique suci 782, 11-12.

133 "E $\tau$ vos to potrawa przyrządzana z roślin strączkowych, zob. Galenus, De rebus boni malique suci 782, 9-11.

${ }^{134}$ Mleko musiało być zresztą zwyczajowym dodatkiem do wyżej wymienionych zup, gdyż mowa jest o nim również w kontekście przyrządzania prosa także u Galena (In Hippocratis de victu acutorum commentaria 4,108$)$.

${ }^{135}$ Por. Galenus, De rebus boni malique suci 782, 6-9.

${ }^{136}$ Por. Dioscurides Pedanius, De materia medica II 97, 1, 2.

${ }^{137}$ Por. Aetius Amidinus, Iatricorum lib. IX 42, 34

${ }^{138}$ Por. Alexander Trallianus, Therapeutica II 407, 23-24.

${ }^{139}$ Por. Aetius Amidinus, Iatricorum lib. IX 42, 34.

${ }^{140}$ Por. tamże IX 42, 65-67.
} 
opartych na kaszy z opisywanego zboża ${ }^{141}$ podaje Filotimos ${ }^{142}$, którego zapiski cytuje w swoim traktacie Orybazjusz (IV w. po Chr.). Pierwsza metoda odnosi się do gotowania drobnej kaszy ${ }^{143}$ jaglanej ${ }^{144}$, druga (znacznie mniej szczegółowa) dotyczy analogicznego produktu, ale o dużo grubszych ziarnach ${ }^{145}$. Ta ostatnia receptura zresztą, jak zaświadcza sam Filotimos, była - zapewne z powodu swojej prostoty - bardziej popularna. Autor pierwszego przepisu zaleca wstępne roztarcie surowego prosa, następnie jego dokładne rozdrobnienie i dalsze rozcieranie po uprzednim dolaniu wody, kolejno - odcedzenie kaszy, a potem gotowanie jej do momentu aż przybierze kleistą konsystencję ugotowanej mąki. Wtedy, jak twierdzi Filotimos, staje się ona nieco cierpka w smaku. Zgodnie z założeniami ówczesnej sztuki medycznej uważano, że taka potrawa jest w stanie zapobiec zablokowaniu przewodu pokarmowego. Natomiast proso gotowane w całości, co praktykowano najczęściej, uważane było za trudniejsze do strawienia, miało czynić jelita bardziej miękkimi i doprowadzać do zmian w wyglądzie stolca, by w końcu powodować powstanie słodkiego soku o ściągających właściwościach.

Proso i włośnica mogły być również składnikiem rzadszych zup lub odwarów. Wiedzę o nich czerpiemy głównie ze źródeł medycznych, co oznacza, że płyny te, prawdopodobnie, miały przede wszystkim zastosowanie lecznicze. Aecjusz z Amidy zaświadcza na przykład, że ze wspomnianych zbóż produkowano kasze ${ }^{146}$, wykorzystywane do gotowania zdrowotnych zup określa-

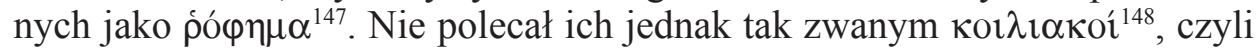
cierpiącym na dolegliwości przewodu pokarmowego, gdyż tak przygotowane proso uważane było za trudne do strawienia i powodujące powstawanie w organizmie szkodliwych soków ${ }^{149}$. Z kolei Dieuches (IV w. prz. Chr.), na którego autorytet powołuje się w swoich Collectiones medicae Orybazjusz jest zdania, że tego rodzaju kasza znakomicie sprawdza się przy leczeniu problemów trawiennych, nie jest ona jednak dobra dla tych, którym doskwiera wysoka gorączka. Jedną z metod przygotowania leczniczego specyfiku proponowaną

\footnotetext{
${ }^{141}$ Por. Oribasius, Collectiones medicae IV 10, 1, 1 - 2, 5.

${ }^{142}$ Był on także jednym z autorytetów dietetycznych, z których korzystał Galen.

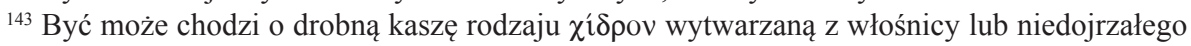

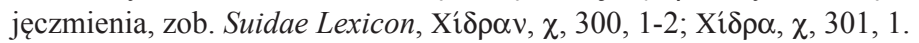

${ }^{144}$ Por. Oribasius, Collectiones medicae IV 10, 1, 1 - 2, 1.

${ }^{145}$ Por. tamże IV 10, 2, 1-5.

${ }^{146}$ W De diaeta (II 45, 13) Hipokratesa jest mowa na temat gotowanego prosa, określanego jako

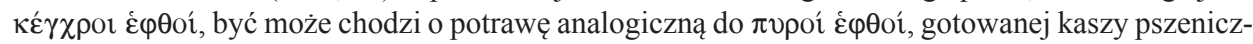
nej (por. Galenus, De alimentorum facultatibus lib. 498, 5 - 500, 3). Obie potrawy charakteryzowane są jako trudno przechodzące przez przewód pokarmowy (Hippocrates, De diaeta II 45, 10-11). Tego

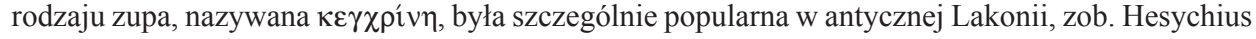

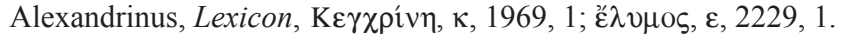

${ }^{147}$ Por. Aetius Amidinus, Iatricorum lib. VIII 31, 18.

${ }^{148}$ Por. tamże IX 35, 1-203.

${ }^{149}$ Por. tamże IX 35, 180-181.
} 
przez Dieuchesa jest ugotowanie, uprzednio namoczonego, odciśniętego i rozdrobnionego w moździerzu oksybafon ${ }^{150}$ prosa w dziesięciu oksybafa wody, z dodatkiem niedużej ilości kopru i soli. Tak przyrządzone, miękkie i odcedzone zboże ${ }^{151}$ mogło być na przykład składnikiem zupy z soczewicy $\varphi \propto \kappa \hat{\eta}$, czy krupniku z jęczmienia $\pi \tau \imath \sigma o ́ v \nu \eta^{152}$. Autor receptury nadmienia nadto, że do pierwszej z potraw dołożyć można surowe nasiona ogórka, do drugiej natomiast domieszać (namoczone, rozdrobnione, ugotowane i odcedzone) orzesz-

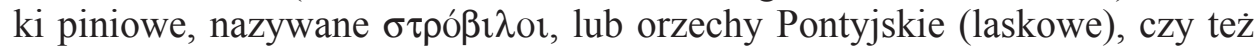
orzechy z Tazos (migdały), zwłaszcza jeżeli otrzymana w ten sposób mieszanina miała mieć to samo działanie ${ }^{153}$ co mleko ${ }^{154}$. Z kolei Aecjusz z Amidy zaznacza, że $\pi \tau \imath \sigma \alpha ́ v \nu \eta^{155} \mathrm{z}$ dodatkiem prosa zwyczajnego zalecana jest osobom cierpiącym na krwotoki z żołądka ${ }^{156}$. Zgodnie z zapiskami Dieuchesa - cytowanymi przez Orybazjusza - zboże, o którym piszemy, mogło również zostać rozgotowane do formy rzadkiej zupy czy kleiku przygotowywanego na rosole baranim lub innych wywarach ${ }^{157}$. W tej postaci podawano je pacjentom będącym w ciężkich stanach chorobowych. Na podstawie źródeł możemy wnioskować, że opisywane zboże było częstym składnikiem rosołu również w kolejnych stuleciach. Świadczy o tym choćby fragment dzieła Therapeutica, w którym Aleksander z Tralles wspomina o dodawaniu włośnicy ${ }^{158}$ do rosołu $\zeta \omega \mu$ ó drobiowego ${ }^{159}$. Dzięki takiemu połączeniu prawdopodobnie powstawała zupa przypominająca znany nam krupnik. Z kolei w bizantyńskim traktacie agronomicznym, Geoponika ${ }^{160}$, odnajdujemy fragment mówiący o praktyce dodawania rozdrobnionej kaszy jaglanej do wywaru, w którym gotowano przepiórki. Zabieg ten służył uniknięciu powikłań zdrowotnych ${ }^{161}$, które mogły wystąpić u konsumującego mięso tych ptaków, jeśli żywiły się one ciemiężycą ${ }^{162}$. Proso nie było jedynie leczniczym dodatkiem do zup, stanowiło także zasadniczy składnik napojów serwowanych osobom cierpiącym na dolegliwości ga-

${ }^{150}$ Oksybafon $=1 / 4$ kotyle $=0,0561$.

${ }^{151}$ Dodatek ten stanowił również substytut oliwy. Zboże przyrządzone w ten sposób, zdaniem medyka, równie dobrze komponowało się z innymi płynnymi potrawami. Por. Oribasius, Collectiones medicae IV 7, 25, 1 - 27, 1.

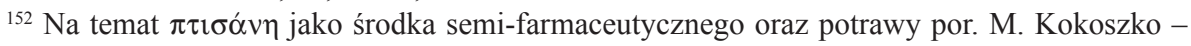
Z. Rzeźnicka - K. Jagusiak, Health and Culinary Art, s. 161-162.

${ }^{153}$ Zapewne chodziło o zwiększenie pożywności potrawy.

${ }^{154}$ Por. Oribasius, Collectiones medicae IV 7, 25, 1 - 27, 1.

${ }^{155}$ Por. Aetius Amidinus, Iatricorum lib. VIII 69, 86.

${ }^{156}$ Por. tamże VIII 69, 67-70.

${ }^{157}$ Por. Oribasius, Collectiones medicae IV 7, 10, 1-5.

${ }^{158}$ Por. Alexander Trallianus, Therapeutica II 219, 20.

${ }^{159}$ Por. tamże II 219, 7-10.

${ }^{160}$ Por. Cassianus Bassus, Geoponica XIV 24, 2.

${ }^{161}$ Zatrucie objawiało się bólami głowy i omdleniami.

${ }^{162}$ Veratrum nigrum L. i Veratrum album L. Wywar z opisywanego zboża w postaci kleiku serwowany był osobom, które nie zdołały uchronić się przed zatruciem pokarmowym, zob. Cassianus Bassus, Geoponica XIV 24, 2. 
stryczne. We fragmentach dzieł Dieuchesa zawartych w Collectiones medicae odnajdujemy przepis na pozornie niegotowany, ale pożywny trunek z prosa i włośnicy podawany przy problemach trawiennych ${ }^{163}$. Pisze on, iż zboża te pozbawione łusek są dobrym pożywieniem dla osób, których przewód pokarmowy cechuje się nadmiarem żółci i którzy z powodu tej dolegliwości często wydalają wodnisty kał. By temu zaradzić, należało wymienione zboża drobno rozetrzeć w wodzie (biorąc przynajmniej oksybafon wody na osobę), a następnie masę tę przecedzić przez szmatkę do kotyle ${ }^{164}$ wody. W końcu do otrzymanego w wyniku przecedzenia płynu wypadało dolać nieco wytrawnego wina i taki napój podać pacjentowi na pusty żołądek. Do prosa i włośnicy można też było dodać, jeszcze przed rozdrobnieniem ziaren, nieco orzechów Eubejskich (kasztanów) wraz z ich wewnętrzną łuską, a uzyskany w ten sposób płyn podać osobom gorączkującym. W Synopsis ad Eustathium filium odnajdujemy ponownie analogiczny wypis z dzieła Dieuchesa ${ }^{165}$. W rzeczonym fragmencie mamy jednak do czynienia z dość istotną zmianą. Mianowicie, w drugiej wersji tekstu wzmiankowanego medyka, jest mowa na temat zagotowania ${ }^{166}$ płynu powstałego w wyniku obróbki prosa. Zatem końcowy produkt staje się w świetle nowych danych raczej odwarem, który może być też nazwany zupą. Warto uwzględnić fakt, iż ten drugi wariant wchodzi w skład fragmentu Synopsis ad Eustathium filium Orybazjusza, zatytułowanym $O$ przygotowywaniu odwa-

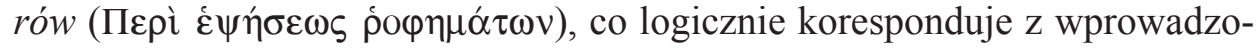
ną informacją o gotowaniu płynu uzyskanego w wyniku przecedzenia prosa, a skutkiem tego potwierdza prawidłowość lekcji dzieła Dieuchesa. Z kolejnej poczynionej przez niego wzmianki na temat konsumpcji prosa zwyczajnego ${ }^{167}$ zachowanej, tym razem w Collectines medicae, dowiadujemy się, że osobom $\mathrm{z}$ dolegliwościami gastrycznymi podawano wywary z domieszką wysuszonej skrobi, $\alpha^{\prime} \mu v \lambda o v^{168}$. Dodawano ją więc do gotowanego prosa ${ }^{169}$, rozgotowanego

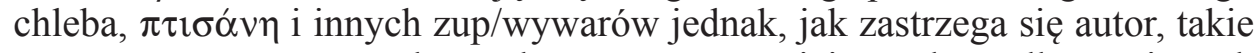
potrawy z warzyw strączkowych uważano za mniej przydatne dla trawionych gorączką ${ }^{170}$.

Na zakończenie warto dodać, że z opisywanego zboża nie sporządzano wyłącznie napojów o zastosowaniu medycznym. Atenajos z Naukraris przy-

${ }^{163}$ Por. Oribasius, Collectiones medicae IV 7, 15, 1 - 18, 1.

${ }^{164}$ Kotyle = ok. 0, 291.

${ }^{165}$ Por. Oribasius, Synopsis ad Eustathium filium IV 35, 16, 1 - 19, 1; w niniejszym opracowaniu posługiwano się wydaniem: Oribasii Synopsis ad Eustathium. Libri ad Eunapium, ed. I. Raeder, Lipsiae - Berolini 1926 (reprint Amsterdam 1964), 1-313.

${ }^{166}$ Por. tamże IV 35, 18, 1.

${ }^{167}$ Por. tenże, Collectiones medicae IV 8, 6, 2.

${ }^{168}$ Produkt ten otrzymywano przede wszystkim z pszenicy, ale także i z roślin strączkowych. O sposobie przygotowania skrobi z pszenicy zob. Cato Marcius Porcius, De agri cultura LXXXVII. Więcej na temat ó $\mu v \lambda o v$, zob. Dalby, Food, s. 349; Berdowski, Przysmaki Katona, s. 180-181.

${ }^{169}$ Zapewne chodzi o zupę z prosa.

${ }^{170}$ Por. Oribasius, Collectiones medicae IV 8, 6, 1 - 7, 2. 
tacza fragment dzieła, zmarłego około 475 r. przed Chr., Hekatajosa z Miletu, który wspomina o produkowaniu w Pajonii napitku alkoholowego, swoistego piwa z prosa i rdestu $^{171}$ nazywanego $\pi \alpha \rho \alpha \beta i ́ \eta^{172}$.

Kasza i mąka jaglana wymieniana jest w źródłach przede wszystkim jako tańszy zamiennik półproduktów wytwarzanych z bardziej popularnych gatunków zbóż, jak pszenica. Nie znaczy to, że potrawy przygotowane z mąki z prosa zwyczajnego bądź włośnicy charakteryzowały się gorszą jakością. $\mathrm{Z}$ powodzeniem przygotowywano z nich chleb, madzę i puls - dania będące podstawą diety w Grecji, Rzymie i Bizancjum. Kasza jaglana i przyrządzony z niej słodki placek - libum miały w kulturze grecko-rzymskiej znaczenie sakralne. Ówcześni medycy potrafili wykorzystać zdrowotne właściwości tego zboża przygotowując z niego leczniczy $\pi$ ó $\tau$ đos przeciw dezynterii. Używali też kaszy jaglanej jako dodatku do zup ( $\varphi \alpha \kappa \eta \hat{,}, \pi \tau \imath \sigma \alpha ́ v \eta, \zeta \omega \mu o ́ \varsigma)$ w kuracjach chorób układu trawiennego.

\section{MILLET IN ANCIENT AND BYZANTINE CUISINE}

\section{(Summary)}

The present article deals with some culinary applications of millet in Antiquity and Byzantine period, as demonstrated in select Greek and Roman literary sources (Athenaeus of Naucratis, Pedanius Dioscurides, Galen, Oribasius, Aetius of Amida, Alexander of Tralles, Symeon Seth, Geoponica, Byzantine lexica, Cato, Columella, Antimus and Apicius).

The authors of the article start their analysis with presenting two kinds of millet, which ancient and Byzantine people were familiar with, namely Greek

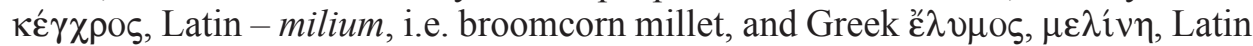
- panicum, i.e. foxtail millet.

Subsequently, they demonstrate suitability of the cereals for bread baking. As result, they prove that millet bread was fairly popular and appreciated, even though Greek dietitians promoted the doctrine that millet was suitable for the purpose of bread production only in the time of scarcity of other, better quality grains. Accordingly, they specify various kinds of bread and describe diverse sorts of ovens (furnus, furniculus, i $\pi v$ ós, testum) it was baked in. The authors also write about one of the ancient desserts, occasionally made of millet flour, namely about libum.

Then, the authors of the article discuss Greek $\mu \hat{\alpha} \zeta \alpha$ and Roman puls, which were two kinds of foods eaten (instead of bread) by a considerable fraction of ancient and Byzantine society and which could also be prepared from the analyzed cereal. The discussion is exemplified with some extant recipes.

Ultimately, the authors of the study refer to the evidence left by medical writers (Galen, Oribasius, Aetius of Amida, Alexander of Tralles), as they discuss soups/

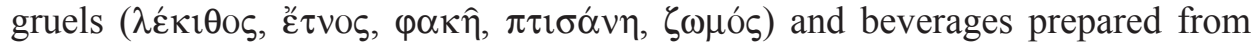

\footnotetext{
${ }^{171}$ Oman (Inula graveolens).

${ }^{172}$ Athenaeus, Deipnosophistae X 447d.
} 
millet, which were said to possess some medical values (and, as the sources reveal, were profited from mostly to cure alimentary tract disorders).

Słowa kluczowe: antyczna i bizantyńska gastronomia, antyczna i bizantyńska medycyna, antyczne i bizantyńskie potrawy zbożowe, konsumpcja prosa zwyczajnego i włośnicy w starożytności i Bizancjum.

Key words: ancient and Byzantine gastronomy, ancient and Byzantine medicine, cereals in Antiquity and Byzantium, broomcorn and foxtail millet as food in Antiquity and Byzantium. 
